\title{
Design, synthesis and biological activity of new neurohypophyseal hormones analogues conformationally restricted in the $N$-terminal part of the molecule. Highly potent OT receptor antagonists
}

\author{
Anna Kwiatkowska • Monika Ptach • \\ Lenka Borovičková · Jiřina Slaninová • \\ Bernard Lammek • Adam Prahl
}

Received: 26 June 2011 / Accepted: 26 September 2011/Published online: 29 October 2011

(C) The Author(s) 2011. This article is published with open access at Springerlink.com

\begin{abstract}
In this study we present the synthesis and some pharmacological properties of fourteen new analogues of neurohypophyseal hormones conformationally restricted in the $N$-terminal part of the molecule. All new peptides were substituted at position 2 with cis-1-amino-4-phenylcyclohexane-1-carboxylic acid (cis-Apc). Moreover, one of the new analogues: [cis-Apc $\left.{ }^{2}, \mathrm{Val}^{4}\right] \mathrm{AVP}$ was also prepared in $N$-acylated forms with various bulky acyl groups. All the peptides were tested for pressor, antidiuretic, and in vitro uterotonic activities. We also determined the binding affinity of the selected compounds to human OT receptor. Our results showed that introduction of $c i s-\mathrm{Apc}^{2}$ in position 2 of either AVP or OT resulted in analogues with high antioxytocin potency. Two of the new compounds, $\left[\mathrm{Mpa}^{1}\right.$, cis-Apc $\left.{ }^{2}\right] \mathrm{AVP}$ and $\left[\mathrm{Mpa}^{1}\right.$, cis-Apc $\left.{ }^{2}, \mathrm{Val}^{4}\right] \mathrm{AVP}$, were exceptionally potent antiuterotonic agents $\left(\mathrm{pA}_{2}=8.46\right.$ and 8.40, respectively) and exhibited higher affinities for the human OT receptor than Atosiban $\left(K_{\mathrm{i}}\right.$ values 5.4 and $9.1 \mathrm{nM})$. Moreover, we have demonstrated for the first time that $N$-terminal acylation of AVP analogue can improve its selectivity. Using this approach, we obtained compound $\mathrm{Aba}\left[\right.$ cis-Apc $\left.{ }^{2}, \mathrm{Val}^{4}\right] \mathrm{AVP}$ (XI) which turned out to be a moderately potent and exceptionally selective OT antagonist $\left(\mathrm{pA}_{2}=7.26\right)$.
\end{abstract}

A. Kwiatkowska $(\bowtie) \cdot$ M. Ptach · B. Lammek · A. Prahl

Faculty of Chemistry, Institute of Organic Synthesis,

University of Gdańsk, Sobieskiego 18/19,

80-952 Gdańsk, Poland

e-mail: aniak@chem.univ.gda.pl

L. Borovičková · J. Slaninová

Institute of Organic Chemistry and Biochemistry,

Academy of Sciences of the Czech Republic,

Flemingovo sq. 2, 16610 Prague, Czech Republic
Keywords Oxytocin antagonists · Atosiban ·

Neurohypophyseal hormones analogues .

Arginine vasopressin (AVP) - Antidiuretic hormone .

Binding affinity

$\begin{array}{ll}\text { Abbreviations } \\ \text { Aba } & \text { 4-Aminobenzoic acid } \\ \text { Aca } & \text { 1-Adamantanecarboxylic acid } \\ \text { Acc } & \text { 1-Aminocyclohexane-1-carboxylic acid } \\ \text { AVP } & \text { Arginine vasopressin } \\ \text { cis-Apc } & \begin{array}{l}\text { cis-1-amino-4-phenylcyclohexane-1- } \\ \text { carboxylic acid }\end{array} \\ \text { Dip } & \text { 3,3-Diphenyl-L-alanine } \\ \text { D-Dip } & \text { 3,3-Diphenyl-D-alanine } \\ \text { DMTMM } & \text { 4-(4,6-Dimethoxy-1,3,5-triazin-2-yl)-4- } \\ & \text { methylmorpholinium chloride } \\ \text { FDA } & \text { Food and Drug Administration Agency } \\ \text { Igl } & \text { L- } \alpha \text {-(2-Indanyl)glycine } \\ \text { D-Igl } & \text { D- } \alpha \text {-(2-Indanyl)glycine } \\ t \text {-Bba } & \text { 4-tert-butylbenzoic acid } \\ \text { Hba } & \text { 4-Hydroxybenzoic acid } \\ \text { HEPES } & \text { 4-(2-hydroxyethyl)-1- } \\ & \text { piperazineethanesulfonic acid } \\ \text { OT } & \text { Oxytocin } \\ \text { SIADH } & \text { Syndrome of inappropriate antidiuretic } \\ & \text { hormone hypersecretion }\end{array}$

Introduction

The neurohypophyseal hormones, arginine vasopressin (AVP) and oxytocin (OT), are cyclic nonpeptides which differ from each other only by two of nine amino acids residues (Fig. 1). Main physiological roles played by AVP 
are the regulation of water balance, the control of blood pressure, and the secretion of adrenocorticotropin hormone (ACTH) (Barberis et al. 1998, 1999). Another neurohypophyseal hormone, OT is classically associated with female reproduction (lactation and parturition) (Gimpl and Fahrenholz 2001; Lee et al. 2009).

Both hormones are synthesized as pre-prohormones in the magnocellular cells of the hypothalamic supraoptic (SON) and paraventricular nuclei (PVN) and secreted as mature active peptides from the posterior pituitary gland into the circulation (Zing et al. 1998; Acher 1993). Moreover, they are released into the central nervous system and act as neuromodulators and neurotransmitters (Landgraf and Neumann 2004). Arginine vasopressin was reported to primarily regulate typical male social behaviours (vocal communication, aggression, and paternal care) (Goodson and Bass 2001). Oxytocin was shown to be mainly involved in maternal behaviour (Insel and Fernald 2004). Moreover both neuropeptides modulate a wide variety of other behaviours, including social recognition, learning, stress, anxiety and depression (Bielsky and Young 2004; Caldwell et al. 2008; Frank and Landgraf 2008).

The AVP and OT receptor family consists of four subtypes of receptors: $\mathrm{V}_{1 \mathrm{~A}}, \mathrm{~V}_{1 \mathrm{~B}}, \mathrm{~V}_{2}$, and OTR. All these receptors belong to the large family of $\mathrm{G}$ protein-coupled receptors (GPCRs) and mediate different pharmacological effects of the hormones. $\mathrm{V}_{1 \mathrm{~A}}$ receptors are expressed in many body tissues (including vascular smooth muscles, liver, kidney, platelets, spleen) and modulate the vasopressor actions of AVP, gluconeogenesis, and platelet aggregation (Zingg 1996). $\mathrm{V}_{1 \mathrm{~B}}$ receptors present in the pituitary, pancreas and adrenals mediate the ACTH-release from the anterior pituitary gland (Jard et al. 1987). Moreover, both $\mathrm{V}_{1 \mathrm{~A}}$ and $\mathrm{V}_{1 \mathrm{~B}}$ receptors were found in brain, where they are involved in higher brain functions (Landgraf and Neumann 2004; Hernando et al. 2001; Frank and Landgraf 2008). $V_{2}$ receptors, located in the renal tubule and particularly the collecting ducts, mediate antidiuretic responses to AVP (Zingg 1996). OT is involved in the control of labor, milk ejection and many social and behavioral functions via interaction with its receptors (OTR) expressed in the uterus, mammary glands, and some

\section{AVP: $\quad H-C y s^{1}-$ Tyr $^{2}-$ Phe $^{3}-\mathrm{GIn}^{4}-\mathrm{Asn}^{5}-\mathrm{Cys}^{6}-\mathrm{Pro}^{7}-\mathrm{Arg}^{8}-\mathrm{Gly}{ }^{9}-\mathrm{NH}_{2}$

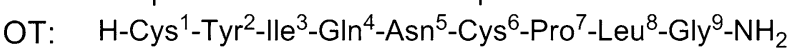

Fig. 1 Amino acid sequence of arginine vasopressin (AVP) and oxytocin (OT) regions of the central nervous system (Zingg 1996; Gimpl and Fahrenholz 2001). The neurohypophyseal hormones receptors show a high degree of homology (35-50\% of sequence identity) (Wheatley et al. 1993). This, along with the similar structure of both hormones, may be a reason for the overlap of pharmacological profiles of OT and AVP.

Arginine vasopressin is essential for osmotic and cardiovascular homeostasis and impairment of its synthesis, secretion or metabolism causes some serious clinical disorders including diabetes insipidus, SIADH, congestive heart failure (Verbalis 2003; Goldsmith 2006). Considerable progress has been made in designing specific AVP analogues in order to treat those disorders (Manning et al. 2008). For example, the $V_{2}$ agonist 1-deamino-8-D-arginine vasopressin (dDAVP, trade name Desmopressin) is used in patients with central diabetes insipidus to reduce urine production and water loss (Vande Walle et al. 2007). Desmopressin is, however, far from being an ideal medication because it is more potent $V_{1 B}$ agonist than a $V_{2}$ agonist in humans (Saito et al. 1997). On the other hand, in the recent years, there has been increasing interest in OT receptor antagonists because of their potential therapeutic value as tocolytic compounds (Romero et al. 2000). Of the many OT antagonists described to date, only one, Atosiban $\left(\mathrm{d}\left[\mathrm{D}-\mathrm{Tyr}(\mathrm{Et})^{2}, \mathrm{Thr}^{4}\right] \mathrm{OVT}\right.$, trade name Tractocile) has been approved (in Europe) for the treatment of preterm labor (Vatish and Thornton 2002). Unfortunately, it is highly non-selective for OT receptors versus AVP $\mathrm{V}_{1 \mathrm{~A}}$ receptors (Manning et al. 1995). Parallel to the development of potent and selective peptide agonist and antagonists, the research of non-peptide agonists and antagonists was carried out. Despite the impressive efforts that have been devoted to the synthesis of many non-peptide analogues, only one vasopressin $V_{2} / V_{1}$ antagonist and one vasopressin $\mathrm{V}_{2}$ antagonist have been approved by the FDA for clinical use (Manning et al. 2008, 2010). Thus the design of neurohypophyseal hormones analogues that selectively interact with appropriate receptors is still a matter of interest.

Many research groups investigate potential strategies to develop potent and selective analogues of AVP and OT. Generally, it has been reported that the conformation of the $N$-terminal part of neurohypophyseal hormones analogues is crucial for their pharmacological activity (Lebl 1987; Manning and Sawyer 1993). For example, replacement of $\mathrm{Tyr}^{2}$ with bulky or sterically restricted substituents is favorable for generation of effective antagonistic analogues (Manning et al. 2005). Also, in our laboratory we have shown that such an approach could result in analogues with very interesting pharmacological properties (Kowalczyk et al. 2006; Derdowska et al. 2005). In 2004, we described the synthesis and some pharmacological properties of new AVP analogues having 1-aminocyclohexane-1-carboxylic acid (Acc, also known as $\mathrm{Ac}_{6} \mathrm{c}$ ) in position 2 (Kowalczyk 
Fig. 2 a Structure of unnatural amino acid cis-Apc and for comparison Acc b structure of bulky acyl groups used in the present study
(A)<smiles>NC1(C(=O)O)CCCCC1</smiles>

Acc<smiles>N[C@]1(C(=O)O)CC[C@H](c2ccccc2)CC1</smiles>

(B)<smiles>O=C(O)C12CC3CC(CC(C3)C1)C2</smiles>

Aca<smiles>Nc1ccc(C(=O)O)cc1</smiles>

Aba<smiles>CC(C)(C)c1ccc(C(=O)O)cc1</smiles>

$t$-Bba<smiles>O=C(O)c1ccc(O)cc1</smiles>

Hba et al. 2004). This modification resulted in four highly potent antidiuretic agonists $\left(\left[\mathrm{Mpa}^{1}, \mathrm{Acc}^{2}\right] \mathrm{AVP},\left[\mathrm{Acc}^{2}\right.\right.$, $\left.\mathrm{Val}^{4}\right]$ AVP, $\left[\mathrm{Mpa}^{1}, \mathrm{Acc}^{2}, \mathrm{D}-\mathrm{Arg}^{8}\right] \mathrm{VP}, \quad$ and $\left[\mathrm{Mpa}^{1}, \mathrm{Acc}^{2}\right.$, $\left.\mathrm{Val}^{4}{ }^{4} \mathrm{D}-\mathrm{Arg}^{8}{ }^{8} \mathrm{VP}\right)$ with different pressor and uterotonic activities. Later, we showed that introduction of 3,3diphenyl-L-alanine (Dip) or its D-enantiomer (D-Dip) into position 2 of AVP and some of its analogues resulted in compounds having strikingly different biological properties in comparison with those of the parent hormone (Kwiatkowska et al. 2009). Their antidiuretic activity was preserved and prolonged, while their uterotonic activity was transformed into antioxytocic one and the effect on blood pressure was eliminated. Moreover, four of new compounds, $\left[\mathrm{Mpa}^{1}, \mathrm{D}-\mathrm{Dip}^{2}\right] \mathrm{AVP},\left[\mathrm{Mpa}^{1}{ }^{1} \mathrm{D}-\mathrm{Dip}^{2}, \mathrm{Val}^{4}\right] \mathrm{AVP},\left[\mathrm{Mpa}^{1}\right.$, D-Dip $\left.{ }^{2}, \mathrm{D}-\mathrm{Arg}^{8}\right] \mathrm{VP}$, and $\left[\mathrm{Mpa}^{1}{ }^{1} \mathrm{D}-\mathrm{Dip}^{2}, \mathrm{Val}^{4}{ }^{4} \mathrm{D}-\mathrm{Arg}^{8}\right] \mathrm{VP}$, were exceptionally potent antidiuretic agents with significantly prolonged activities. Our more recent study reported a series of AVP analogues substituted in position 2 with $\alpha-2$ indanylglycine or its D-enantiomer (Igl or D-Igl, respectively) (Kwiatkowska et al. 2010). Those compounds were moderate or potent OT antagonists and practically did not interact with $V_{1 A}$ and $V_{2}$ receptors. It is worth to emphasize that only a single modification of position 2 of AVP with Igl was sufficient to obtain selective and potent antioxytocic agent.

Continuing our efforts to obtain potent and selective analogues of neurohypophyseal hormones we investigated the effectiveness of steric restrictions and bulky substituents in the $N$-terminal part of the AVP and OT molecules. We decided to check how substitution of position 2 with bulky cis-1-amino-4-phenylcyclohexane-1-carboxylic acid (cis-Apc, see Fig. 2a) would reflect in the values of biological potency of the analogues. The cis-Apc differs from 1-aminocyclohexane-1-carboxylic acid (Acc, Fig. 2a) previously used in our laboratory (Kowalczyk et al. 2004; Jastrzębska et al. 2003) by the presence of a phenyl moiety and was chosen in order to find out how the enlargement of the side chain and change of its character for aromatic one will influence the activity of resulting analogues. Fourteen new analogues of neurohypophyseal hormones have been designed and their structures are summarized in Fig. 3. First, seven analogues of AVP and its derivatives having additional substitutions $\left(\mathrm{Cpa}^{1}, \mathrm{Mpa}^{1}\right.$ and/or $\mathrm{Val}^{4}$ and/or D-Arg ${ }^{8}$ ) were prepared (I-VII). Next, four $N$-acylated

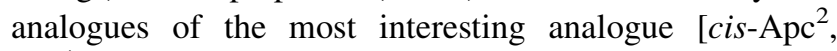
$\mathrm{Val}^{4}$ ]AVP (III) were synthesized (VIII-XI). These analogues were obtained by acylation of the $N$-terminus of the above peptide with 1-adamantanecarboxylic acid (Aca), 4-tert-butylbenzoic acid ( $t$-Bba), 4-hydroxybenzoic (Hba), and 4-aminobenzoic acid (Aba), see Fig. 2b). The third group of analogues was designed by $c i s-\mathrm{Apc}^{2}$ substitution at position of OT, $\left[\mathrm{Mpa}^{1}\right] \mathrm{OT}$, and $\left[\mathrm{Cpa}^{1}\right] \mathrm{OT}$ (XII-XIV).

\section{Materials and methods}

\section{Materials}

All solvents and reagents were obtained from commercial suppliers and used without further purification. All the 


\begin{tabular}{|c|c|c|c|c|}
\hline \multicolumn{5}{|c|}{$\begin{array}{l}\mathbf{Y} \text { - } \mathbf{X}^{1} \text { - } \mathbf{X}^{2} \text { - Phe - } \mathbf{X}^{3} \text { - Asn - Cys - Pro - } \mathbf{X}^{4} \text { - Gly - } \mathrm{NH}_{2}(\mathbf{A V P}) \\
\text { where: }\end{array}$} \\
\hline \multirow[t]{2}{*}{$\mathrm{Y}=\mathrm{H}$} & $\mathrm{X}^{1}=\mathrm{Cys}$ & $\mathrm{X}^{2}=$ cis-Apc & & I \\
\hline & $\mathrm{X}^{1}=\mathrm{Mpa}$ & $\mathrm{X}^{2}=$ cis- $\mathrm{Apc}$ & & II \\
\hline \multirow[t]{2}{*}{$\mathrm{Y}=\mathrm{H}$} & $\mathrm{X}^{1}=\mathrm{Cys}$ & $\mathrm{X}^{2}=$ cis- $\mathrm{Apc}$ & $\mathrm{X}^{3}=$ Val & III \\
\hline & $\mathrm{X}^{1}=\mathrm{Mpa}$ & $\mathrm{X}^{2}=$ cis-Apc & $\mathrm{X}^{3}=\mathrm{Val}$ & IV \\
\hline \multirow[t]{3}{*}{$\mathrm{Y}=\mathrm{H}$} & $\mathrm{X}^{1}=\mathrm{Cys}$ & $\mathrm{X}^{2}=$ cis- $\mathrm{Apc}$ & $\mathrm{X}^{4}=\mathrm{D}-\mathrm{Arg}$ & $\mathbf{V}$ \\
\hline & $\mathrm{X}^{1}=\mathrm{Mpa}$ & $\mathrm{X}^{2}=$ cis-Apc & $\mathrm{X}^{4}=\mathrm{D}-\mathrm{Arg}$ & VI \\
\hline & $\mathrm{X}^{1}=\mathrm{Cpa}$ & $\mathrm{X}^{2}=$ cis- $\mathrm{Apc}$ & & VII \\
\hline $\mathrm{Y}=\mathrm{Aca}$ & $\mathrm{X}^{1}=\mathrm{Cys}$ & $\mathrm{X}^{2}=$ cis-Apc & $\mathrm{X}^{3}=\mathrm{Val}$ & VIII \\
\hline $\mathrm{Y}=\mathrm{t}-\mathrm{Bba}$ & $\mathrm{X}^{1}=\mathrm{Cys}$ & $\mathrm{X}^{2}=$ cis- $\mathrm{Apc}$ & $\mathrm{X}^{3}=\mathrm{Val}$ & IX \\
\hline $\mathrm{Y}=\mathrm{Hba}$ & $\mathrm{X}^{1}=\mathrm{Cys}$ & $\mathrm{X}^{2}=$ cis- $\mathrm{Apc}$ & $\mathrm{X}^{3}=\mathrm{Val}$ & $\mathbf{x}$ \\
\hline $\mathrm{Y}=\mathrm{Aba}$ & $\mathrm{X}^{1}=\mathrm{Cys}$ & $\mathrm{X}^{2}=$ cis- $\mathrm{Apc}$ & $\mathrm{X}^{3}=\mathrm{Val}$ & XI \\
\hline \multicolumn{5}{|c|}{$\begin{array}{l}\text { Y - } \mathbf{X}^{1} \text { - } \mathbf{X}^{2} \text { - Ile - Gln - Asn - Cys - Pro - Leu - Gly - } \mathrm{NH}_{2} \text { (OT) } \\
\text { where: }\end{array}$} \\
\hline \multirow[t]{3}{*}{$\mathrm{Y}=\mathrm{H}$} & $\mathrm{X}^{1}=\mathrm{Cys}$ & $\mathrm{X}^{2}=$ cis- $\mathrm{Apc}$ & & XII \\
\hline & $\mathrm{X}^{1}=\mathrm{Mpa}$ & $\mathrm{X}^{2}=$ cis $-\mathrm{Apc}$ & & XIII \\
\hline & $\mathrm{X}^{1}=\mathrm{Cpa}$ & $\mathrm{X}^{2}=$ cis- $\mathrm{Apc}$ & & XIV \\
\hline
\end{tabular}

Fig. 3 Structure of the new vasopressin and oxytocin analogues

amino acid derivatives were purchased from NovaBiochem, except Fmoc-cis-Apc and Boc-cis-Apc, which were provided by NeoMPS. Mpa(Trt) was obtained as described for Cys(Trt) (Bodanszky et al. 1984) using 3-mercaptopropionic acid instead of L-cysteine hydrochloride. Cpa (Mob) was synthesized using a procedure described in the literature (Rekowski and Lammek 1987). High-performance liquid chromatography was carried out on a Waters (analytical and semi-preparative) chromatograph equipped with a UV detector $(\lambda=226$ and $254 \mathrm{~nm})$. The purity of the peptides was determined on Vydac $\mathrm{C}_{18}$ or Hypersil ODS $\mathrm{C}_{18}$ or Hypersil BDS $\mathrm{C}_{18}$ column $(5 \mu \mathrm{m}, 4.6 \times 250 \mathrm{~mm})$. The following solvent systems were used: [A] $0.1 \%$ aqueous TFA, [B] acetonitrile/ $0.1 \%$ aqueous TFA (80:20 v/v). Semipreparative HPLC was carried out using a Waters $\mathrm{C}_{18}$ column $(15 \mu \mathrm{m}, 100 \AA$ \&, $7.8 \times 300 \mathrm{~mm})$. The mass spectra of the peptides were recorded on a MALDI TOF mass spectrometer.

Peptide synthesis and purification

All the peptides, except analogues VII and XIV, were obtained manually by solid-phase synthesis (scale $150 \mu \mathrm{mol}$ ) on a polystyrene resin-TentaGel S RAM (Rapp Polymere, capacity $0.23 \mathrm{mmol} / \mathrm{g}$ ), according to standard coupling procedures and $\mathrm{Fmoc} / \mathrm{Bu}^{\mathrm{t}}$ strategy (Fields and Noble 1990). Analogues VIII-XI were additionally coupling with bulky acetyl groups (Fmoc-Aba, Aca, $t$-Bba, Hba) in the final step of synthesis. For protection of the side chain functionalities, Fmoc-Asn(Trt), Fmoc-Gln(Trt), FmocCys(Trt), Fmoc-Arg(Pbf) and Fmoc-D-Arg(Pbf) were used.
Stepwise synthesis of a peptide analogues was achieved with 2-1 $H$-(benzotriazole-1-yl)-1,1,3,3-tetramethyluronium tetrafluoroborate/1-hydroxybenzotriazole (TBTU/HOBt) or $O$-(7-azabenzotriazol-1-yl)-1,1,3,3-tetramethyluronium hexafluorophosphate/1-hydroxy-7-azabenzotriazole (HATU/ HOAt) as coupling agents in the presence of NMM in mixture of DMF/NMP (1:1 v/v) (Zimmer et al. 1992; Sabatino et al. 2003). The couplings after Fmoc-cis-Apc were mediated by DMTMM in the presence of DIPEA in the NMP (Kunishima et al. 1999). In most cases, the Fmocamino acids and acetyl groups were coupled at a threefold excess for $2.5 \mathrm{~h}$ at room temperature. The completeness of reaction was monitored by the Kaiser test (Kaiser et al. 1970) or chloranil test (Christensen 1979). Recoupling was performed when the test was positive. The Fmoc groups were removed by treatment with $20 \%$ piperidine in DMF for 5 and $10 \mathrm{~min}$. Cleavage of peptide-linker bond and removal of the side chain protecting groups were accomplished using solution of TFA: $\mathrm{H}_{2} \mathrm{O}: \mathrm{TIS}: \mathrm{PhOH}$ (9.0:2.5:2.5:5.0) in $3 \mathrm{~h}$ at room temperature. The solutions of the released peptides were filtered and evaporated in vacuo to a volume of about $1 \mathrm{~mL}$. Then the peptides were precipitated with diethyl ether to afford crude products. Analogues V, XII synthesized using an Fmoc strategy was obtained in very low yield, and we resynthesized them by Boc chemistry.

Peptides V, VII, XII, and XIV were synthesized manually using Boc chemistry on a methoxybenzhydryl resin (MBHA resin, Senn Chemicals AG, 1\% DVB, 200-400 mesh, $0.67 \mathrm{mmol} / \mathrm{g}$ ) on a scale of $200 \mu \mathrm{mol}$ according to standard procedures, using in situ neutralization (Schnőlzer et al. 1992). For protection of side chain functionalities, Boc-Arg(Tos), Boc-D-Arg(Tos), Boc-Cys(Mob), Cpa(Mob) were used. Fully protected peptide resin was synthesized according to standard procedures involving (i) deprotection steps $33 \%$ TFA/DCM in the presence of anisole (1\%), 5 and $10 \mathrm{~min}$; (ii) neutralization with 10\% TEA/DCM, 5 and $10 \mathrm{~min}$; (iii) couplings of Boc-amino acid; $3 \mathrm{~h}$ at room temperature. In most cases, the amino acids were coupled at threefold excess using TBTU/HOBt/NMM in the mixture of DMF/NMP $(1: 1 \mathrm{v} / \mathrm{v})$, and if necessary amino acid/ HATU/HOBt/NMM (1:1:1:2) in mixture of DMF/NMP $(1: 1 \mathrm{v} / \mathrm{v})$ for recoupling steps. After $3 \mathrm{~h}$ coupling time, the Kaiser test (Kaiser et al. 1970) or chloranil test (Christensen 1979) was performed to estimate the completeness of the reaction. After completion of the synthesis, the protected peptidyl or acylpeptidyl resins were treated with $10 \mathrm{~mL}$ of liquid hydrogen fluoride (HF) containing $1 \mathrm{~mL}$ of anisole at $-70^{\circ} \mathrm{C}$ and stirred for $60 \mathrm{~min}$ at $0^{\circ} \mathrm{C}$ (Stewart 1984). After removal of $\mathrm{HF}$ and anisole in vacuo, the mixture was washed successively with anhydrous diethyl ether, then with acetic acid and the solution was diluted with methanol.

The formation of the disulfide bond (cyclization) was carried out with a $0.1 \mathrm{M} \mathrm{I}_{2}$ a solution of methanol and 
Table 1 Physiochemical properties of peptides I-XIV

\begin{tabular}{|c|c|c|c|c|c|c|}
\hline \multirow[t]{2}{*}{ Analogue } & & \multirow[t]{2}{*}{ Formula } & \multirow[t]{2}{*}{ Yield $^{\mathrm{a}}(\%)$} & \multirow[t]{2}{*}{ HPLC $T_{R}(\min )^{b}$} & \multicolumn{2}{|l|}{$\left[\mathrm{M}+\mathrm{H}^{+}\right]$} \\
\hline & & & & & Calculated & Found \\
\hline$\left[\right.$ cis-Apc $\left.{ }^{2}\right] \mathrm{AVP}$ & $\mathbf{I}$ & $\mathrm{C}_{50} \mathrm{H}_{71} \mathrm{~N}_{15} \mathrm{O}_{11} \mathrm{~S}_{2}$ & 55.8 & $14.96^{\mathrm{c}}$ & 1121.5 & 1122.3 \\
\hline$\left[\mathrm{Mpa}^{1}, c i s-\mathrm{Apc}^{2}\right] \mathrm{AVP}$ & II & $\mathrm{C}_{50} \mathrm{H}_{70} \mathrm{~N}_{14} \mathrm{O}_{11} \mathrm{~S}_{2}$ & 76.8 & 22.34 & 1106.4 & 1106.5 \\
\hline$\left[c i s-\mathrm{Apc}^{2}, \mathrm{Val}^{4}\right] \mathrm{AVP}$ & III & $\mathrm{C}_{50} \mathrm{H}_{72} \mathrm{~N}_{14} \mathrm{O}_{10} \mathrm{~S}_{2}$ & 56.7 & $16.47^{\mathrm{c}}$ & 1091.5 & 1092.3 \\
\hline$\left[\mathrm{Mpa}^{1}, c i s-\mathrm{Apc}^{2}, \mathrm{Val}^{4}\right] \mathrm{AVP}$ & IV & $\mathrm{C}_{50} \mathrm{H}_{71} \mathrm{~N}_{13} \mathrm{O}_{10} \mathrm{~S}_{2}$ & 82.8 & $18.80^{\mathrm{c}}$ & 1077.5 & 1078.3 \\
\hline$\left[c i s-\mathrm{Apc}^{2}, \mathrm{D}-\mathrm{Arg}^{8}\right] \mathrm{VP}$ & $\mathbf{V}$ & $\mathrm{C}_{50} \mathrm{H}_{71} \mathrm{~N}_{15} \mathrm{O}_{11} \mathrm{~S}_{2}$ & 41.8 & 19.24 & 1121.4 & 1122.9 \\
\hline$\left[\mathrm{Mpa}^{1}, c i s-\mathrm{Apc}^{2}, \mathrm{D}-\mathrm{Arg}^{8}\right] \mathrm{VP}$ & VI & $\mathrm{C}_{50} \mathrm{H}_{70} \mathrm{~N}_{14} \mathrm{O}_{11} \mathrm{~S}_{2}$ & 68.6 & 23.70 & 1106.4 & 1107.6 \\
\hline$\left[\mathrm{Cpa}^{1}\right.$, cis-Apc $\left.{ }^{2}\right] \mathrm{AVP}$ & VII & $\mathrm{C}_{55} \mathrm{H}_{78} \mathrm{~N}_{14} \mathrm{O}_{11} \mathrm{~S}_{2}$ & 57.9 & 25.07 & 1174.2 & 1175.4 \\
\hline $\mathrm{Aca}\left[c i s-\mathrm{Apc}^{2}, \mathrm{Val}^{4}\right] \mathrm{AVP}$ & VIII & $\mathrm{C}_{61} \mathrm{H}_{86} \mathrm{~N}_{14} \mathrm{O}_{11} \mathrm{~S}_{2}$ & 89.9 & $27.60^{\mathrm{d}}$ & 1254,5 & 1255.9 \\
\hline$t$-Bba $\left[c i s-\mathrm{Apc}^{2}, \mathrm{Val}^{4}\right] \mathrm{AVP}$ & IX & $\mathrm{C}_{61} \mathrm{H}_{84} \mathrm{~N}_{14} \mathrm{O}_{11} \mathrm{~S}_{2}$ & 91.8 & $13.07^{\mathrm{e}}$ & 1252,3 & 1253.9 \\
\hline $\mathrm{Hba}\left[\operatorname{cis}-\mathrm{Apc}^{2}, \mathrm{Val}^{4}\right] \mathrm{AVP}$ & $\mathbf{X}$ & $\mathrm{C}_{57} \mathrm{H}_{76} \mathrm{~N}_{14} \mathrm{O}_{12} \mathrm{~S}_{2}$ & 90.5 & $19.96^{\mathrm{d}}$ & 1212,4 & 1213.9 \\
\hline $\mathrm{Aba}\left[c i s-\mathrm{Apc}^{2}, \mathrm{Val}^{4}\right] \mathrm{AVP}$ & XI & $\mathrm{C}_{57} \mathrm{H}_{76} \mathrm{~N}_{14} \mathrm{O}_{12} \mathrm{~S}_{2}$ & 92.4 & $19.96^{\mathrm{d}}$ & 1211,4 & 1212.8 \\
\hline$\left[c i s-\mathrm{Apc}^{2}\right] \mathrm{OT}$ & XII & $\mathrm{C}_{47} \mathrm{H}_{72} \mathrm{~N}_{12} \mathrm{O}_{11} \mathrm{~S}_{2}$ & 43.0 & 20.10 & 1044.5 & 1045.4 \\
\hline$\left[\mathrm{Mpa}^{1},{ }^{2} i s-\mathrm{Apc}^{2}\right] \mathrm{OT}$ & XIII & $\mathrm{C}_{47} \mathrm{H}_{71} \mathrm{~N}_{11} \mathrm{O}_{11} \mathrm{~S}_{2}$ & 74.8 & 22.19 & 1029.4 & 1030.9 \\
\hline$\left[\mathrm{Cpa}^{1}\right.$, cis-Apc $\left.{ }^{2}\right] \mathrm{OT}$ & XIV & $\mathrm{C}_{52} \mathrm{H}_{89} \mathrm{~N}_{11} \mathrm{O}_{11} \mathrm{~S}_{2}$ & 61.6 & 27.05 & 1097.5 & 1098.3 \\
\hline
\end{tabular}

[A] $0.1 \%$ aqueous trifluoroacetic acid (TFA), [B] acetonitrile : $0.1 \%$ aqueous TFA (80:20 v/v)

a Yields were calculated on the basis of the amino acid content of the resin

b Linear gradient from 20 to $80 \%$ of [B] in [A] for 30 min, Hypersil ODS $\mathrm{C}_{18}$ column

c Linear gradient from 20 to $80 \%$ of $[\mathrm{B}]$ in [A] for 20 min, Vydac $\mathrm{C}_{18}$ column

d Linear gradient from 30 to $90 \%$ of [B] in [A] for 30 min, Hypersil ODS $\mathrm{C}_{18}$ column

e Linear gradient from 60 to $90 \%$ of [B] in [A] for 60 min, Hypersil BDS $\mathrm{C}_{18}$ column

acetic acid using a standard procedure (Flouret et al. 1979). The solvents were evaporated under reduced pressure and the resulting materials were dissolved in water, frozen and lyophilized to give the final crude oxidized products. The crude compounds were desalted on a Sephadex G-15 column, and eluted with aqueous acetic acid (30\%) at a flow rate of $3 \mathrm{~mL} / \mathrm{h}$. After freeze-drying, the fractions comprising the major peak were purified by semi-preparative HPLC (Waters Corporation, Milford, MA, USA) on reversed-phase support Waters $\mathrm{C}_{18}$ column $(15 \mu \mathrm{m}, 100 \AA$ A $7.8 \times 300 \mathrm{~mm}$ ) with a linear gradients running from 30 to $55 \%$ [B] for 90 min for analogues I-VI, X-XIII from 40 to $65 \%$ [B] for 90 min for analogues VIII and IX, and from 45 to $65 \%$ [B] for $80 \mathrm{~min}$ for analogues VII and XIV, all at a flow rate of $2.5 \mathrm{~mL} / \mathrm{min}$ and UV detection at 226 and $254 \mathrm{~nm}$. The appropriate fractions were pooled and lyophilized. The purity of the peptides was controlled using analytical HPLC (Waters Corporation, Milford, MA, USA) with a Vydac $\mathrm{C}_{18}$ or Hypersil ODS $\mathrm{C}_{18}$ or Hypersil BDS $\mathrm{C}_{18}$ column and matrix-assisted laser desorption/ionization time of flight MALDI TOF mass spectroscopy (molecular ion) was used to confirm the identity of the pure products. According to both HPLC and MS, the purity of peptides exceeded $98 \%$. Their physicochemical properties are presented in Table 1.

\section{Biological evaluation}

Bioassay methods

Wistar rats were used in all experiments. Handling of the experimental animals was done under supervision of the Ethics Committee of the Academy of Sciences according to $\S 23$ of the law of the Czech Republic no. 246/1992.

The uterotonic test was carried out in vitro on the strips of rat uterus in the absence of magnesium ions (Holton 1948; Munsick 1960; Slaninová 1987). Rats in induced estrus by the injection of estrogen $48 \mathrm{~h}$ before the experiments were used. After decapitation, the uterine horns were excised, longitudinally cut, placed into a bathing chamber and hooked up to recorder of contractions. The height of the single isometric contraction of a uterine strip was measured. In principle, cumulative dosing was applied in the experiments, i.e. doses of standard (in the presence or absence of analogues) or of the analogue were added successively to the uterus in the organ bath in doubling concentrations and at $1 \mathrm{~min}$ intervals without the fluid being changed until the maximal response (the highest contraction) was obtained. The dose-response curves were constructed. Synthetic oxytocin was used as standard. Each new analogue was tested using uteri from 3 to 5 different animals; the values in the Table are averages \pm SEM. 
The vasopressor test was performed using phenoxybenzamine-treated male rats (Dekanski 1952) under urethane anesthesia. Arginine vasopressin was used as a standard. Changes of the arterial blood pressure were registered. Dose (single administration into vena femoralis) response curves were constructed in the presence and absence of an antagonist. The antagonist was administered 1 min prior to the administration of the standard. Each analogue was tested in 3-5 independent experiments, the values in the Table are averages \pm SEM.

With agonists, the activity was expressed in IU/mg, whereas with antagonists as $\mathrm{pA}_{2}$. The $\mathrm{pA}_{2}$ values represent the negative logarithm to the base 10 of the average molar concentration of an antagonist that reduces the response to $2 x$ units of the agonist to the response to $x$ units of the agonist (Slaninová 1987). The volume of distribution in the in vivo experiments is arbitrarily taken as $67 \mathrm{ml} / \mathrm{kg}$. The responses to standard doses of oxytocin or vasopressin were stable for several hours, without problems with tachyphylaxis.

Tests to assess the antidiuretic property were conducted on conscious male rats in a modified Burn test (Burn et al. 1950; Vávra et al. 1974). In the standard manner with hydrated rats, the animals having fasted for $16 \mathrm{~h}$ were weighed and then given tap water through a stomach catheter. The water load was $4 \%$ of the body weight. Immediately after the water load, the tested substances (or physiological saline as control) were administered subcutaneously at doses of $0.001-100 \mathrm{nmol} / \mathrm{kg}$. The rats were then placed in individual metabolic cages, and their urine was collected over a $5 \mathrm{~h}$ period. The time $t_{1 / 2}$ in which the rats excreted half the water load was determined and then plotted against the dose. As the dose-response curves were not parallel, such doses were chosen for calculating the compound's potency which yield $t_{1 / 2}$ equal to $60 \mathrm{~min}$ (the so-called threshold doses equal to the value of $t_{1 / 2}$ obtained with the physiological solution) and $t_{1 / 2}$ equal to $200 \mathrm{~min}$. On each day of the experiment, 21 rats divided into 5 groups of 4 or 5 animals were administered different doses of different compounds; in an average each compound was tested in 3-5 different doses, each dose being tested in 2 or 3 independent experiments (different days, different rats). The results were thus expressed in IU/mg in comparison to AVP (the value $450 \mathrm{IU} / \mathrm{mg}$ was taken for AVP for both $t_{1 / 2}$ $60 \mathrm{~min}$ and $t_{1 / 2} 200 \mathrm{~min}$ ).

\section{Binding affinity determination}

Binding affinities to the human oxytocin receptor were determined as described in (Fahrenholz et al. 1984), using tritiated oxytocin from NEN Life Science, Boston, MA, USA. In brief, a crude membrane fraction of HEK OTR cells, i.e. HEK cells having stable expressed human OT receptor (kindly donated by Dr. G. Gimpl (Gimpl et al. 1997), was incubated with [3H]OT (2 nM) and various concentrations of peptides $(0.1-10,000 \mathrm{nM})$ for $30 \mathrm{~min}$ at $35^{\circ} \mathrm{C}$. The total volume of the reaction mixture was $0.25 \mathrm{ml}$ and the buffer used was $50 \mathrm{mM}$ HEPES at $\mathrm{pH} 7.6$ containing $10 \mathrm{mM} \mathrm{MnCl} 2$ and $1 \mathrm{mg} / \mathrm{ml}$ bovine serum albumin. The reaction was terminated by quick filtration on a Brandel cell harvester. Oxytocin was used as a control and for determination of non-specific binding. Binding affinities were expressed as $K_{\mathrm{i}}$ values calculated according to the expression $K_{\mathrm{i}}=\mathrm{IC}_{50} /\left[\left(\mathrm{c}_{3 \mathrm{HOT}} / K_{\mathrm{dOT}}\right)+1\right]$, where $K_{\mathrm{dOT}}$ is taken as $1.8 \mathrm{nM}$ (Soloff and Swartz 1974).

\section{Results}

Peptide synthesis and purification

Fourteen new neurohypophyseal hormone analogues were obtained as crude products in about $41-92 \%$ yields. After HPLC purification, their purity was better than $98 \%$ as determined by analytical HPLC. The MALDI TOF mass spectrometry confirmed identity of the purified peptides. Their physicochemical characteristics are given in Table 1.

\section{Biological activity}

Pharmacological characteristics of the new analogues together with those of AVP and some related peptides are summarized in Table 2. The activities of the new compounds were determined by the in vitro rat uterotonic test in the absence of magnesium ions, the rat pressor test, and by the antidiuretic assay using conscious rats, as described in the "Biological evaluation" Section.

A comparison of the antidiuretic activities of the new analogues with those published previously is complicated by the fact that different methods were used for the activity determination and that the dose-response curves of the analogues and that of standard AVP have different slopes. It is therefore necessary to provide two potency values, the first resulting from comparison of the threshold doses of AVP with those of the analogues (antidiuresis time $t_{1 / 2}$ $60 \mathrm{~min}$ ) and the second originating from comparison of doses giving an antidiuresis time of $200 \mathrm{~min}$. The antidiuresis time $\left(t_{1 / 2}\right)$ corresponds to the time in which the rat excretes half of the water load. For AVP, the activity has arbitrarily been set to $465 \mathrm{IU} / \mathrm{mg}$ for both responses. None of the new compounds exhibited diuretic or, in other words, anti-antidiuretic activity

The new peptides (I-VI) showed weak antidiuretic potency, about 10-465 times lower than that of AVP at the threshold level (60 min). However, their activity was significantly prolonged, they were about 2-19 fold more 
Table 2 Pharmacological properties of the new neurohypophyseal hormones analogues together with the values for AVP and some related analogues

\begin{tabular}{|c|c|c|c|c|}
\hline \multirow[t]{2}{*}{ Analogue } & & \multicolumn{3}{|l|}{ Activity* } \\
\hline & & $\begin{array}{l}\text { Uterotonic in vitro no } \\
\mathrm{Mg}^{2+} \mathrm{IU} / \mathrm{mg} \text { or } \mathrm{pA}_{2}\end{array}$ & $\begin{array}{l}\text { Pressor** IU/mg } \\
\text { or } \mathrm{pA}_{2}\end{array}$ & $\begin{array}{l}\text { Antidiuretic*** IU/mg } \\
60 \mathrm{~min}(200 \mathrm{~min})\end{array}$ \\
\hline \multicolumn{2}{|l|}{$\mathrm{AVP}^{\mathrm{a}}$} & 17 & 412 & 465 \\
\hline \multicolumn{2}{|l|}{$\mathrm{OT}^{\mathrm{a}}$} & 450 & 5 & 5 \\
\hline \multicolumn{2}{|l|}{$\left[\mathrm{Mpa}^{1}\right] \mathrm{OT}^{\mathrm{a}}$} & 803 & 1.44 & 19 \\
\hline \multicolumn{2}{|c|}{ Atosiban, d[D-Tyr $\left.(E t)^{2}, \mathrm{Thr}^{4}\right] \mathrm{OVT}^{\mathrm{b}, \mathrm{c}}$} & $7.71 \pm 0.05$ & $\mathrm{pA}_{2}=6.14 \pm 0.02$ & $\mathrm{pA}_{2}=5.9$ \\
\hline \multicolumn{2}{|l|}{$\left[\mathrm{Acc}^{2}\right] \mathrm{AVP}^{\mathrm{d}}$} & $\mathrm{pA}_{2} \sim 5.6$ & 56.6 & $750-900(\sim 9,300)$ \\
\hline \multicolumn{2}{|l|}{$\left[\mathrm{Mpa}^{1}, \mathrm{Acc}^{2}\right] \mathrm{AVP}^{\mathrm{e}}$} & $\mathrm{pA}_{2} \sim 5.6(0.7 \mathrm{IU} / \mathrm{mg})$ & $17.2 \pm 0.8$ & $4,500(50,000)$ \\
\hline \multicolumn{2}{|l|}{$\left[\mathrm{Acc}^{2}, \mathrm{Val}^{4}\right] \mathrm{AVP}^{\mathrm{e}}$} & $\mathrm{pA}_{2}=6.9$ & $0.9 \pm 0.30$ & $2,300(23,000)$ \\
\hline$\left[c i s-\mathrm{Apc}^{2}\right] \mathrm{AVP}$ & $\mathbf{I}$ & $\mathrm{pA}_{2}=7.47 \pm 0.30$ & $\mathrm{pA}_{2}=6.73$ & $10(2,000)$ \\
\hline$\left[\mathrm{Mpa}^{1}\right.$, cis-Apc $\left.{ }^{2}\right] \mathrm{AVP}$ & II & $\mathrm{pA}_{2}=8.46 \pm 0.20$ & $\mathrm{pA}_{2}=7.41$ & $45(9,000)$ \\
\hline$\left[c i s-\mathrm{Apc}^{2}, \mathrm{Val}^{4}\right] \mathrm{AVP}$ & III & $\mathrm{pA}_{2}=8.22 \pm 0.11$ & $\mathrm{pA}_{2}=6.85$ & $15(2,000)$ \\
\hline$\left[\mathrm{Mpa}^{1}\right.$, cis-Apc $\left.{ }^{2}, \mathrm{Val}^{4}\right] \mathrm{AVP}$ & IV & $\mathrm{pA}_{2}=8.40 \pm 0.19$ & $\mathrm{pA}_{2}=7.04$ & $20(4,500)$ \\
\hline$\left[c i s-\mathrm{Apc}^{2}, \mathrm{D}-\mathrm{Arg}^{8}\right] \mathrm{VP}$ & $\mathbf{V}$ & $\mathrm{pA}_{2}=7.98+0.14$ & $\mathrm{pA}_{2} \sim 7.1$ & $1(200)$ \\
\hline$\left[\mathrm{Mpa}^{1}\right.$, cis $\left.-\mathrm{Apc}^{2}, \mathrm{D}-\mathrm{Arg}^{8}\right] \mathrm{VP}$ & VI & $\mathrm{pA}_{2}=8.16+0.02$ & $\mathrm{pA}_{2} \sim 7.1$ & $5(1,000)$ \\
\hline$\left[\mathrm{Cpa}^{1}, c i s-\mathrm{Apc}^{2}\right] \mathrm{AVP}$ & VII & $\mathrm{pA}_{2}=7.85+0.14$ & $\mathrm{pA}_{2} \sim 6.2$ & $0.05(1)$ \\
\hline $\mathrm{Aca}\left[c i s-\mathrm{Apc}^{2}, \mathrm{Val}^{4}\right] \mathrm{AVP}$ & VIII & $\mathrm{pA}_{2}=5.7$ & 0 & $<0.01(<0.5)$ \\
\hline$t-\mathrm{Bba}\left[c i s-\mathrm{Apc}^{2}, \mathrm{Val}^{4}\right] \mathrm{AVP}$ & IX & $10.1+3.8 \mathrm{IU} / \mathrm{mg}$ & 0 & $<0.01(<0.5)$ \\
\hline $\mathrm{Hba}\left[c i s-\mathrm{Apc}^{2}, \mathrm{Val}^{4}\right] \mathrm{AVP}$ & $\mathbf{X}$ & $\mathrm{pA}_{2}=7.61$ & $\mathrm{pA}_{2} \sim 6.4$ & $<0.01(<0.5)$ \\
\hline $\mathrm{Aba}\left[c i s-\mathrm{Apc}^{2}, \mathrm{Val}^{4}\right] \mathrm{AVP}$ & $\mathbf{X I}$ & $\mathrm{pA}_{2}=7.26+0.40$ & 0 & 0 \\
\hline$\left[c i s-\mathrm{Apc}^{2}\right] \mathrm{OT}$ & XII & $\mathrm{pA}_{2}=7.89+0.07$ & $\mathrm{pA}_{2} \sim 5.75$ & ND \\
\hline$\left[\mathrm{Mpa}^{1}, c i s-\mathrm{Apc}^{2}\right] \mathrm{OT}$ & XIII & $\mathrm{pA}_{2}=8.11+0.18$ & $\mathrm{pA}_{2} \sim 6.0$ & 0 \\
\hline$\left[\mathrm{Cpa}^{1}, c i s-\mathrm{Apc}^{2}\right] \mathrm{OT}$ & XIV & $\mathrm{pA}_{2}=7.97+0.24$ & $\mathrm{pA}_{2} \sim 6.73$ & ND \\
\hline
\end{tabular}

* The values are given as averages \pm SEM, $n=3-5$

** 0 means no activity up to the dose of $0.15 \mathrm{mg} / \mathrm{kg}$ of experimental animal

*** Activity was estimated on the threshold level of activity $60 \mathrm{~min}$ and on the level of the 200 min activity (in parentheses); activity of AVP taken as $465 \mathrm{IU} / \mathrm{mg}$ at both levels, $N D$ no data available

Biological activities of the other analogues reported here as references are taken from the literature: ${ }^{\mathrm{a}} \mathrm{Lebl}(1987),{ }^{\mathrm{b}} \mathrm{Melin}$ et al. (1986), ${ }^{\mathrm{c}} \mathrm{Manning}$ et al. (1995), ${ }^{\mathrm{d} J a s t r z e ̨ b s k a ~ e t ~ a l . ~(2003), ~}{ }^{\mathrm{e}}$ Kowalczyk et al. (2004)

effective than AVP at the $t_{1 / 2}$ level of 200 min, with the exception of peptide $\mathbf{V}\left[\right.$ cis-Apc ${ }^{2}$,D-Arg $\left.{ }^{8}\right] \mathrm{VP}$ which turned out to be a moderately potent agonist (about $43 \%$ of antidiuretic potency of AVP). The $N$-acylated AVP analogues (VIII-XI) and peptide VII ([Cpa $\left.\left.{ }^{1}, c i s-\mathrm{Apc}^{2}\right] \mathrm{AVP}\right)$ exhibited either no (analogue XI) or only negligible (compounds VII-X) antidiuretic activity. Among the oxytocin analogues, the antidiuretic activity was estimated for one compound (XIII) only and it was found inactive in this test.

Regarding the pressor activity, all the analogues modified at position 2 with cis-Apc were either weak (peptides VII, XII) or moderate (compounds I-VI, XIII, XIV) antagonists. The $N$-acylation of peptide III ([cis-Apc ${ }^{2}$, $\left.\mathrm{Val}^{4}\right] \mathrm{AVP}$ ) eliminated its effect on blood pressure (analogues VIII, IX, XI), with the exception of compound $\mathbf{X}\left(\mathrm{Hba}\left[c i s-\mathrm{Apc}^{2}, \mathrm{Val}^{4}\right] \mathrm{AVP}\right)$ which remained a weak antagonist $\left(\mathrm{pA}_{2} \sim 6.4\right)$.
As can be seen in Table 2, in the uterotonic test most of the analogues exhibited moderate (peptide $\mathbf{I}, \mathrm{pA}_{2}=7.47$ ) or high (compounds II-VII and XII-XIV, $\mathrm{pA}_{2}$ values ranging from 7.89 to 8.46 ) anti-oxytocic potency. The $\mathrm{N}$-acylation had an inconsistent effect, in the case of peptide VIII, the antioxytocin activity was strongly decreased, in the case of peptides $\mathbf{X}$ and $\mathbf{X I}$ the antagonism was much less decreased and surprisingly, acylation of the [cis$\left.\mathrm{Apc}^{2}, \mathrm{Val}^{4}\right] \mathrm{AVP}$ peptide with 4-tert-butylbenzoic acid transformed the high antiuterotonic activity into agonistic one (analogue IX, $10.1 \pm 3.8 \mathrm{IU} / \mathrm{mg}$ ).

Binding affinity

The results of pharmacological tests on rats were supplemented by determination of the affinities of selected analogues to human oxytocin receptors stably expressed on the 
Table 3 Binding affinities of Atosiban and AVP analogues (I-IV)

\begin{tabular}{llc}
\hline Analogue & & $K_{\mathrm{i}}(\mathrm{nM})^{\mathrm{a}}$ \\
\hline Atosiban, d[D-Tyr(Et) $\left.{ }^{2}, \mathrm{Thr}^{4}\right] \mathrm{OVT}^{\mathrm{b}}$ & & $71.5 \pm 21.2$ \\
{$\left[\right.$ cis-Apc $\left.^{2}\right] \mathrm{AVP}$} & I & $110 \pm 26$ \\
{$\left[\mathrm{Mpa}^{1}\right.$, cis- $\left.^{\mathrm{A}} \mathrm{Apc}^{2}\right] \mathrm{AVP}$} & II & $5.4 \pm 1.2$ \\
{$\left[\right.$ cis-Apc $\left.^{2}, \mathrm{Val}^{4}\right] \mathrm{AVP}$} & III & $88.8 \pm 30.2$ \\
{$\left[\mathrm{Mpa}^{1}\right.$, cis- $\left.^{2} \mathrm{Apc}^{2}, \mathrm{Val}^{4}\right] \mathrm{AVP}$} & IV & $9.1 \pm 0.7$ \\
\hline
\end{tabular}

${ }^{a} K_{\mathrm{i}}$ Concentration of peptide leading to half-maximal specific binding deduced from competition experiments, experiments performed in HEK cells

b The biological activity of the Atosiban is taken from the literature: Reversi et al. (2005)

HEK cells using tritiated oxytocin (Table 3). The results in Table 3 show that two of the new analogues ([Mpa ${ }^{1}$, cis$\left.\mathrm{Apc}^{2}\right] \mathrm{AVP}(\mathbf{I I})$ and $\left.\left[\mathrm{Mpa}^{1},{ }^{1} i s-\mathrm{Apc}^{2}, \mathrm{Val}^{4}\right] \mathrm{AVP}(\mathbf{I V})\right)$ had higher affinities for the human OT receptor than the commonly used OT antagonist, Atosiban (Melin et al. 1986; Manning et al. 1995). On the other hand, their counterparts with Cys $^{1}$ (peptides I, III) displayed the binding affinity comparable with that of Atosiban $\left(K_{\mathrm{i}}=110 \pm 26\right.$ and $K_{\mathrm{i}}=88.8 \pm 30.2$, respectively).

\section{Discussion}

Our previous studies have demonstrated that modification of the $\mathrm{N}$-terminal part of the AVP molecule, especially by reduction of conformational freedom, has a dramatic impact on pharmacological activities of its analogues (Kowalczyk et al. 2006; Derdowska et al. 2005; Kwiatkowska et al. 2009, 2010). In continuation of our research that focuses on obtaining potent and selective neurohypophyseal hormone analogues with agonistic or antagonistic properties, we now report on biological properties of a series of new analogues modified at position 2 with cis-1amino-4-phenylcyclohexane-1-carboxylic acid.

The first group of compounds was designed by $c i s-\mathrm{Apc}^{2}$ substitution of AVP and of some of its analogues having additional modifications at positions 1,4 , and 8 . As can be seen in Table 2, this modification is sufficient to transform the compounds from agonists into a moderately potent blockers of oxytocic uterotonic activity (e.g. [cis$\mathrm{Apc}^{2}$ ]AVP, $\mathrm{pA}_{2}=7.47$ ). Moreover, combination of the cis-Apc ${ }^{2}$ modification with $\mathrm{Cpa}^{1}$ or $\mathrm{Mpa}^{1}$ and/or $\mathrm{Val}^{4}$ substitution and/or inversion of configuration of $\mathrm{Arg}^{8}$ significantly increased anti-oxytocic potency of the resulting analogues (peptides II-VII). The most potent uterotonic antagonists were obtained by deamination of position 1 of the following peptides: $\left[c i s-\mathrm{Apc}^{2}\right] \mathrm{AVP},\left[c i s-\mathrm{Apc}^{2}, \mathrm{Val}^{4}\right]$ $\mathrm{AVP}$, and $\left[c i s-\mathrm{Apc}^{2}, \mathrm{Val}^{4}{ }^{4} \mathrm{D}-\mathrm{Arg}^{8}\right] \mathrm{AVP}$. It is worth emphasizing that these compounds (II, IV and VI) with anti-oxytocic potency $\mathrm{pA}_{2}$ of $8.46,8.40$ and 8.16 , respectively, turned out to be more potent antagonists than Atosiban $\left(\mathrm{pA}_{2}=7.71\right.$, Manning et al. 1995). The cis-Apc amino acid differs from Acc residue used by us in a previous study in the presence of a phenyl moiety (Fig. 2a), thus restoring the aromatic character of the side chain at position 2. Peptides modified with $\mathrm{Acc}^{2}$, which were considered as models for the new compounds (I-VII) exhibited only weak antiuterotonic activities, with the exception of peptide $\left[\mathrm{Cpa}^{1}, \mathrm{Acc}^{2}\right] \mathrm{AVP}$ which displayed moderate anti-oxytocic properties $\left(\mathrm{pA}_{2}=7.33\right.$, Jastrzębska et al. 2003). It is noteworthy to mention that our previous results showed that the presence of other than $\mathrm{Tyr}^{2}$ aromatic amino acid residues at position 2, e.g. L-1-Nal enantiomers, 2-aminoindane-2-carboxylic acid, 3,3-diphenylalanine enantiomers, and $\alpha$-2-indanylglycine enantiomers (Derdowska et al. 2005; Kowalczyk et al. 2007; Kwiatkowska et al. 2009, 2010) was favourable for generation of effective anti-oxytocic or antidiuretic agents. The results presented in this paper strongly support those previous findings. Moreover, two of the new analogues, $\left[\mathrm{Mpa}^{1}{ }^{1}\right.$, cis$\left.\mathrm{Apc}^{2}\right] \mathrm{AVP}$ and $\left[\mathrm{Mpa}^{1}, c i s-\mathrm{Apc}^{2}, \mathrm{Val}^{4}\right] \mathrm{AVP}$, exhibited a much higher affinity for the human OT receptor $\left(K_{\mathrm{i}}\right.$ values $=5.4-9.1 \mathrm{nM}$ ) than Atosiban (Table 3).

Regarding the antidiuretic tests, all new analogues exhibited either very low (peptides I-IV, and VI, about $1-10 \%$ of the vasopressin activity) or only negligible (compounds $\mathbf{V}$ and VII) activity at the threshold level (60 min). However, their potency was significantly prolonged as can be seen from the activities calculated at the antidiuresis half time level of $200 \mathrm{~min}$, with the exception of peptide VII. The degree of prolongation was in the case of all analogues mentioned the same, i.e. ca 200 times. The results presented in Table 2 show that two of the new peptides, $\left[\mathrm{Mpa}^{1}{ }^{1}, c i s-\mathrm{Apc}^{2}\right] \mathrm{AVP}$ and $\left[\mathrm{Mpa}^{1}\right.$, cis- $\left.\mathrm{Apc}^{2}, \mathrm{Val}^{4}\right]$ AVP, were even 10-20-fold more effective than AVP at the $200 \mathrm{~min}$ level. Also as far as the antidiuretic activity is concerned, the structural difference between cis-Apc and Acc modification plays an important role as our new cis$\mathrm{Apc}^{2}$-substituted peptides were only weak agonists at the level of $t_{1 / 2} 60 \mathrm{~min}$, while their counterparts with $\mathrm{Acc}^{2}$ exhibited a high antidiuretic potency (Kowalczyk et al. 2004, Jastrzębska et al. 2003). It is interesting to note that the combination of the above mentioned modifications (cisApc or Acc) with additional substitution of position 1 with 1-mercaptocyclohexaneacetic acid (Cpa) resulted in analogues with substantially reduced antidiuretic activity. We have previously noticed this correlation in, for example, the series of AVP analogues modified with 1-aminocyclopentane-1-carboxylic acid (Kowalczyk et al. 2005) and 3,3diphenylalanine enantiomers (Kwiatkowska et al. 2009). This finding suggests that Cpa modification in the $N$-terminus of AVP with either bulky and sterically restricted or 
just sterically restricted amino acid at position 2 is not favourable for interaction with the receptor.

As far as the pressor test is concerned, the new analogues (I-VI) were shown to be moderate antagonists of the pressor response to AVP with the exception of peptide VII which exhibited low antagonistic activity. As shown in Table 2, the $\mathrm{Cpa}^{1}$ modification of the $\left[\right.$ cis-Apc $\left.{ }^{2}\right] \mathrm{AVP}$ molecule again resulted in a decreased activity.

In the uterotonic test, in general, $c i s-\mathrm{Apc}^{2}$ substitution resulted in compounds having high anti-oxytocin potency $\left(\mathrm{pA}_{2}\right.$ values ranging from 7.85 to 8.46). Even two of the new peptides, $\left[\mathrm{Mpa}^{1}, c i s-\mathrm{Apc}^{2}\right] \mathrm{AVP}$ and $\left[\mathrm{Mpa}^{1}\right.$, cis$\mathrm{Apc}^{2}, \mathrm{Val}^{4} \mathrm{JAVP}$, were more potent OT antagonists and exhibited higher affinities for the human OT receptor than Atosiban (the currently available tocolytic agent). However, they are also as non-selective as Atosiban, because of their antidiuretic and antipressor activities.

To enhance the selectivity of our $c i s-\mathrm{Apc}^{2}$ substituted peptides, we tried two different approaches. First, $\mathrm{N}$-acylation of the most active peptide III using 4 different acyl groups (See Fig. 2b) was performed. This approach has been successfully adopted in our laboratory to improve antagonistic potency of bradykinin $\mathrm{B}_{2}$ antagonists in the rat blood pressure assay (Lammek et al. 1990, 1991). The [cis$\left.\mathrm{Apc}^{2}, \mathrm{Val}^{4}\right]$ AVP peptide was chosen as a reference compound for acylation because it showed a very interesting pharmacological profile. This analogue exhibited a high anti-oxytocic potency $\left(\mathrm{pA}_{2}=8.22\right)$ and moderate pressor antagonism $\left(\mathrm{pA}_{2}=6.85\right)$, while its antidiuretic potency was lower than that of AVP but with a significantly prolonged activity. For $N$-terminal acylation we decided to use bulky groups with different chemical character since our previous studies revealed that chemical character of the acids used to modify the bradykinin antagonists was crucial for the activity (Prahl et al. 1997; Trzeciak et al. 2000; Labudda et al. 2007). The other approach involved introduction of cis-Apc in position 2 of oxytocin and its analogues $\left[\mathrm{Mpa}^{1}\right]$ OT and $\left[\mathrm{Cpa}^{1}\right] \mathrm{OT}$.

Acylation of the $N$-terminal part of $\left[\right.$ cis- $\left.\mathrm{Apc}^{2}, \mathrm{Val}^{4}\right] \mathrm{AVP}$ resulted in peptides VIII-XI with strikingly different pharmacological properties as compared to that of the reference analogue (Table 2). While the effect on pressor activity and antidiuretic activity was consistent-in the case of all four different acyl groups there was substantial decrease of activity, regarding the oxytocic activity, the effect was heterogenous. Two of the analogues with either negative $(\mathbf{X})$ or positive $(\mathbf{X I})$ charge on the $N$-terminal acyl group were moderate antagonists in the in vitro uterus test $\left(\mathrm{pA}_{2}=7.26\right.$ and 7.61, respectively) about 4 and 10 times less potent than the mother compound III. The analog modified with bulky 1-adamantanecarboxylic acid (Aca) was shown to be a very weak anti-oxytocic agent $\left(\mathrm{pA}_{2}=5.7\right)$ and surprisingly, the peptide obtained by acylation of the reference compound with 4-tert-butylbenzoic acid transformed its anti-oxytocic activity into an agonistic one $(10.1 \pm 3.8 \mathrm{IU} / \mathrm{mg})$. Thus a small difference in the structure of the acyl group causes pronounced change in the biological activity, see analogues VIII and IX. Moreover, it should be emphasized that the presence of a bulky acyl substituent at the $N$-terminus of $\left[c i s-\mathrm{Apc}^{2}\right.$, $\mathrm{Val}^{4}$ ]AVP significantly improved selectivity of the resulting analogues and led to compound XI ( $\mathrm{Aba}\left[c i s-\mathrm{Apc}^{2}\right.$, $\left.\mathrm{Val}^{4}\right] \mathrm{AVP}$ ) which is a moderately potent and exceptionally selective anti-oxytocic agent. These results demonstrate once more that conformation of the $N$-terminal part of AVP analogues is crucial for their pharmacological activity.

The next group of compounds studied consists of oxytocin analogues: $\left[c i s-\mathrm{Apc}^{2}\right] \mathrm{OT}(\mathbf{X I I}),\left[\mathrm{Mpa}^{1}, c i s-\mathrm{Apc}^{2}\right] \mathrm{OT}$ (XIII) and $\left[\mathrm{Cpa}^{1}, \mathrm{cis}^{-\mathrm{Apc}}{ }^{2}\right] \mathrm{OT}$ (XIV). The results presented in Table 2 show that introduction of cis-Apc in position 2 of OT and some of its analogues resulted in compounds having high antioxytocic potency $\left(\mathrm{pA}_{2}\right.$ values ranging from 7.89 to 8.11) comparable to their AVP counterparts. In the pressor test and antidiuretic test the cis$\mathrm{Apc}^{2}$-substituted OT analogues have mostly much lower activity than the of their AVP counterparts. Only analogue XIV turned out to be moderate antagonists of vasopressin pressor action. When comparing the properties of $\left[\mathrm{Mpa}^{1}\right.$, cis-Apc $\left.{ }^{2}\right] \mathrm{AVP}$ and $\left[\mathrm{Mpa}^{1}\right.$, cis-Apc $\left.{ }^{2}\right] \mathrm{OT}$ (Table 2), they both exhibited a high anti-oxytocic activity $\left(\mathrm{pA}_{2}=8.46\right.$ and 8.11 , respectively) but the oxytocin analogue was distinctly more selective.

\section{Conclusion}

The results of this study demonstrate once more that conformational freedom and bulkiness of the $N$-terminal part of the neurohypophyseal hormone molecules have a significant impact on pharmacological activities. It has clearly been shown that introduction of $c i s-\mathrm{Apc}^{2}$ in position 2 of either AVP or OT resulted in compounds with high antioxytocin potency. Two of the new analogues, $\left[\mathrm{Mpa}^{1}, \mathrm{cis}\right.$ $\left.\mathrm{Apc}^{2}\right] \mathrm{AVP}$ (II) and $\left[\mathrm{Mpa}^{1}, c i s-\mathrm{Apc}^{2}, \mathrm{Val}^{4}\right] \mathrm{AVP}(\mathbf{I V})$, were exceptionally potent anti-uterotonic agents $\left(\mathrm{pA}_{2}=8.46\right.$ and 8.40 , respectively) and exhibited higher affinities for the human OT receptor than Atosiban ( $K_{\mathrm{i}}$ values 5.4 and $9.1 \mathrm{nM}$ ). Moreover, we have demonstrated for the first time that $N$-terminal acylation of AVP analogue can improve its selectivity. Using this approach, we obtained compound $\mathrm{Aba}\left[\mathrm{cis}_{-}-\mathrm{Apc}^{2}, \mathrm{Val}^{4}\right] \mathrm{AVP}$ (XI) which turned out to be a moderately potent and exceptionally selective OT antagonist $\left(\mathrm{pA}_{2}=7.26\right)$. This combination of pharmacological properties makes our new analogues promising candidates for the development of potential tocolytic agents. 
In summary, our study provides new information on the structure-activity relationship of neurohypophyseal hormone analogues and can have an impact on designing selectively acting anti-oxytocic agents. We are undertaking further SAR studies on our $c i s$-Apc ${ }^{2}$-substituted peptides using NMR and theoretical molecular modelling methods to provide structural rationale for the activity results.

Acknowledgments Partial funding for this work was provided by Polish State Committee for Scientific Research under the Grant No. 0230/B/H03/2008/35 and by research project No. Z4055905 of the Academy of Sciences of the Czech Republic.

Open Access This article is distributed under the terms of the Creative Commons Attribution Noncommercial License which permits any noncommercial use, distribution, and reproduction in any medium, provided the original author(s) and source are credited.

\section{References}

Acher R (1993) Neurohypophysial peptide systems: processing machinery, hydroosmotic regulation, adaptation and evolution. Regul Pept 45:1-13

Barberis C, Mouillac B, Durroux T (1998) Structural bases of vasopressin/oxytocin receptor function. $\mathrm{J}$ Endocrinol 156: 223-229

Barberis C, Morin D, Durroux T, Mouillac B, Guillon G, Seyer R, Hibert M, Tribollet E, Manning M (1999) Molecular pharmacology of AVP and OT receptors and therapeutic potential. Drug News Perspect 12:279-292

Bielsky IF, Young LJ (2004) Oxytocin, vasopressin, and social recognition in mammals. Peptides 25:1565-1574

Bodanszky M, Bodanszky A (1984) The Practice of Peptide Synthesis, vol 83. Springer, Berlin

Burn HJ, Finney DJ, Goodwin LG (1950) Biological Standardization, 2nd edn. Oxford University Press, London, p 187

Caldwell HK, Lee HJ, Macbeth AH, Young WS III (2008) Vasopressin: behavioral roles of an "original" neuropeptide. Prog Neurobiol 84:1-24

Christensen TC (1979) A chloroanil color test for monitoring coupling completeness in solid-phase peptide synthesis. In: Gross E, Meienhofer J (eds) Peptidess structure and biological function. Pierce Chemical Company, Rockford, p 385

Dekanski J (1952) The quantitative assay of vasopressin. $\mathrm{Br}$ J Pharmacol 7:567-572

Derdowska I, Prahl A, Kowalczyk W, Janecki M, Melhem S, Trzeciak HI, Lammek B (2005) Influence of enantiomers of 1-napthylalanine in position 2 of AVP and dAVP on their pharmacological properties. Eur J Med Chem 40:63-68

Fahrenholz F, Boer R, Crause P, Fritzsch G, Grzonka Z (1984) Interactions of vasopressin agonists and antagonists with membrane receptors. Eur J Pharmacol 100:47-58

Fields G, Noble R (1990) Solid-phase peptide synthesis utilizing 9-fluorenylmethoxycarbonyl amino acids. Int J Pept Protein Res $35: 161-214$

Flouret G, Terada S, Kato T, Gualtieri R, Lipkowski A (1979) Synthesis of oxytocin using iodine for oxidative cyclization and silica gel adsorption chromatography for purification. Int J Pept Protein Res 13:137-141

Frank E, Landgraf R (2008) The vasopressin system-from antidiuresis to psychopathology. Eur J Pharmacol 583:226-242
Gimpl G, Fahrenholz F (2001) The oxytocin receptor system: structure, function, and regulation. Physiol Rev 81:629-683

Gimpl G, Burger K, Fahrenholz F (1997) Cholesterol as modulator of receptor function. Biochemistry 36:10959-10974

Goldsmith SR (2006) The role of vasopressin in congestive heart failure. Cleve Clin J Med 73:19-23

Goodson JL, Bass AH (2001) Social behavior functions and related anatomical characteristics of vasotocin/vasopressin systems in vertebrates. Brain Res Brain Res Rev 35:246-265

Hernando F, Schoots O, Lolait SJ, Burbach JP (2001) Immunohistochemical localization of the vasopressin $\mathrm{V} 1 \mathrm{~b}$ receptor in the rat brain and pituitary gland: anatomical support for its involvement in the central effects of vasopressin. Endocrinology 142:1659-1668

Holton P (1948) A modification of the method of Dale and Laidlaw for standardization of posterior pituitary extract. Br J Pharmacol Chemother 3:328-334

Insel TR, Fernald RD (2004) How the brain processes social information: searching for the social brain. Annu Rev Neurosci 27:697-722

Jard S, Barberis C, Audigier S, Tribollet E (1987) Neurohypophyseal hormone receptor systems in brain periphery. Prog Brain Res 72:173-187

Jastrzebska B, Derdowska I, Kowalczyk W, Machova A, Slaninowa J, Lammek B (2003) Influence of 1-aminocycloheksane-1-carboxylic acid in position 2 or 3 of AVP and its analogues on their pharmacological properties. J Pept Res 62:70-77

Kaiser E, Colescott RI, Bossinger CD, Cook P (1970) Color test for detection of free terminal amino groups in the solid-phase synthesis of peptides. Anal Biochem 34:595-598

Kowalczyk W, Prahl A, Derdowska I, Dawidowska O, Slaninová J, Lammek B (2004) Highly potent 1-aminocyclohexane-1-carboxylic acid substituted $\mathrm{V}_{2}$ agonists of arginine vasopressin. J Med Chem 47:6020-6024

Kowalczyk W, Prahl A, Dawidowska O, Derdowska I, Sobolewski D, Hartrodt B, Neubert K, Slaninová J, Lammek B (2005) The influence of 1-aminocyclopentane-1-carboxylic acid at position 2 or 3 of AVP and its analogues on their pharmacological properties. J Pept Sci 11:584-588

Kowalczyk W, Prahl A, Derdowska I, Sobolewski D, Olejnik J, Zabrocki J, Borovickova L, Slaninova J, Lammek B (2006) Analogues of neurohypophyseal hormones, oxytocin and arginine vasopressin, conformationally restricted in the N-terminal part of the molecule. J Med Chem 49:2016-2021

Kowalczyk W, Sobolewski D, Prahl A,Derdowska I, Borovicková L, Slaninová J, Lammek B (2007) The Effects of $N$-terminal part modification of arginine vasopressin analogues with 2-aminoindane-2-carboxylic acid: a highly potent $\mathrm{V}_{2}$ agonist. J Med Chem 50:2926-2929

Kunishima M, Kawachi C, Monta J, Terao K, Iwasaki F, Tani S (1999) 4-(4, 6-dimethoxy-1, 3, 5-triazin-2-yl)-4-methylmorpholinium chloride: an efficient condensing agent leading to the formation of amides and esters. Tetrahedron Lett 12: $13159-13170$

Kwiatkowska A, Sobolewski D, Prahl A, Borovicková L, Slaninová J, Lammek B (2009) Arginine vasopressin and its analogues-the influence of position 2 modification with 3, 3-diphenylalanine enantiomers. Highly potent $\mathrm{V}_{2}$ agonists. Eur J Med Chem 44: 2862-2867

Kwiatkowska A, Sleszynska M, Derdowska I, Prahl A, Sobolewski D, Borovicková L, Slaninová J, Lammek B (2010) Novel analogues of arginine vasopressin containing alpha-2-indanylglycine enantiomers in position 2. J Pept Sci 16:15-20

Labudda O, Wierzba T, Sobolewski D, Sleszyńska M, Gawiński Ł, Plackova M, Slaninová J, Prahl A (2007) New bradykinin analogues acylated on the N-terminus: effect on rat uterus and blood pressure. Acta Biochim Pol 54:193-198 
Lammek B, Wang YX, Gavras J, Gavras H (1990) A new highly potent antagonist of bradykinin. Peptides 11:1041-1043

Lammek B, Wang YX, Gavras J, Gavras H (1991) A novel bradykinin antagonist with improved properties. J Pharm Pharmacol 43:887-888

Landgraf R, Neumann ID (2004) Vasopressin and oxytocin release within the brain: a dynamic concept of multiple and variable modes of neuropeptide communication. Front Neuroendocrinol 25:150-176

Lebl M (1987) Analogues with inhibitory properties. In: Lebl M, Jost $\mathrm{K}$, Brtnik F (eds) Handbook of neurohypophyseal hormone analogs, vol II. CRC Press, Boca Raton, pp 17-74

Lee HJ, Macbeth AH, Pagani JH, Young WS (2009) Oxytocin: the great facilitator of life. Prog Neurobiol 88:127-151

Manning M, Sawyer WH (1993) Design, synthesis and some uses of receptor-specific agonists and antagonists of vasopressin and oxytocin. J Receptor Res 13:195-214

Manning M, Miteva K, Pancheva S, Stoev S, Wo NC, Chan WY (1995) Design and synthesis of highly selective in vitro and in vivo uterine receptor antagonists of oxytocin: comparisons with Atosiban. Int J Peptide Protein Res 46:244-252

Manning M, Cheng LL, Stoev S, Wo NC, Chan WY, Szeto HH, Durroux T, Mouillac B, Barberis C (2005) Design of peptide oxytocin antagonists with strikingly higher affinities and selectivities for the human oxytocin receptor than atosiban. J Pept Sci 11:593-608

Manning M, Stoev S, Chini B, Durroux T, Mouillac B, Guillon G (2008) Peptide and non-peptide agonists and antagonists for the vasopressin and oxytocin V1a, V1b, V2 and OT receptors: research tools and potential therapeutic agents. Prog Brain Res 170:473-512

Manning M, Stoev S, Bankowski K (2010) Peptides versus nonpeptides as therapeutics: An exciting challenge for big pharma. In: Lebl M, Mendal M, Jensen KJ, Hoeg-Jensen T (eds) Proceedings of the 31st European peptide symposium, European Peptide Society, pp 366-367

Melin P, Trojnar J, Johansson B, Vilhardt H, Akerlund M (1986) Synthetic antagonists of the myometrial response to vasopressin and oxytocin. J Endocrinol 111:125-131

Munsick RA (1960) Effect of magnesium ion on the response of the rat uterus to neurohypophysial hormones and analogues. Endocrinol 66:451-458

Prahl A, Wierzba T, Wszędybył M, Juzwa W, Lammek B (1997) Design and synthesis of new bradykinin antagonists with N-terminal acylation. Polish J Chem 71:915-922

Rekowski P, Lammek B (1987) Synthesis of modified analogs of 1-(1phenylmethylthiocyclohexane)-acetic acid. Pol J Chem 61:907-911

Reversi A, Rimoldi V, Marrocco T, Cassoni P, Bussolati G, Parenti M, Chini B (2005) The oxytocin receptor antagonist atosiban inhibits cell growth via a "biased agonist" mechanism. J Biol Chem 280:16311-16318

Romero R, Sibai BM, Sanchez-Ramos L, Valenzuela GJ, Veille J-C, Tabor B, Perry KG, Varner M, Goddwin TM, Lane R, Smith J, Shangold G, Creasy GW (2000) An oxytocin receptor antagonist (Atosiban) in the treatment of preterm labor: a randomized, double-blind, placebo-controlled trial with tocolytic rescue. Am J Obstet Gynecol 182:1173-1183

Sabatino G, Mulinacci B, Alcaro MC, Chelli M, Rovero P, Papini AM (2003) Assessment of new 6Cl-HOBt based coupling reagents for peptide synthesis. Part 1: coupling efficiency study. Lett Pept Sci 9:119-123

Saito M, Tahara A, Sugimoto T (1997) 1-Desamino-8-D-arginine vasopressin (DDAVP) as an agonist on $\mathrm{V}_{\mathrm{lb}}$ vasopressin receptor. Biochem Pharmacol 53:171-1717

Schnőlzer M, Alewood P, Jones A, Alewood D, Kent S (1992) In situ neutralization in Boc-chemistry solid phase peptide synthesis. Int J Pept Protein Res 40:180-193

Slaninová J (1987) Fundamental biological evaluation. In: Lebl M, Jost K, Brtnik F (eds) Handbook of neurohypophyseal hormone analogs, vol I. CRC Press, Boca Raton, pp 83-107

Soloff MS, Swartz TL (1974) Characterization of proposed oxytocin receptor in the uterus of the rat and sow. J Biol Chem 249:1376-1381

Stewart JM (1984) Solid phase peptide synthesis. Pierce Chem. Corp, Rockford, p 87

Trzeciak HI, Kozik W, Melhem S, Kania A, Dobrowolski D, Prahl A, Derdowska I, Lammek B (2000) New bradykinin analogs in contraction of rat uterus. Peptides 21:829-834

Vande Walle J, Stockner M, Raes A, Nørgaard JP (2007) Desmopressin 30 years in clinical use: a safety review. Curr Drug Saf. 2:232-238

Vatish M, Thornton S (2002) Oxytocin antagonists. Expert Opin Ther Patents 12:1403-1406

Vávra I, Machová A, Krejčí I (1974) Antidiuretic action of 1-deamino-8-d-arginine vasopressin in unanesthetized rats. Pharmacol Exp Ther 188:241-247

Verbalis JG (2003) Disorders of body water homeostasis. Best Pract Res Clin Endocrinol Metab 17:471-503

Wheatley M, Howl J, Morel A, Davies ARL (1993) Homology between neurohypophysial hormone receptors. Biochem J 296:519-582

Zimmer S et al (1992) Schneider CH and Eberle AN (eds.) Proceedings of 22nd European Peptides Symposium, Peptides Leiden 1993, p 393

Zing HH, Bourque CW, Bichet DG (1998) Vasopressin and Oxytocin, Plenum Press, New York

Zingg HH (1996) Vasopressin and oxytocin receptors. Baillieres Clin Endocrinol Metab 10:75-96 